Pobrane z czasopisma Annales H - Oeconomia http://oeconomia.annales.umcs.pl Data: 26/04/2023 14:14:58

DOI:10.17951/h.2015.59.2.259

\begin{tabular}{lc}
\hline & A N N A L E S \\
UNIVERSITATIS & MARIAE C URIE-S KŁ ODOW S K A \\
LUBLIN - POLONIA & 2015 \\
VOL. XLIX, 2 & SECTIO H \\
\hline Uniwersytet Marii Curie-Skłodowskiej w Lublinie, Katedra Gospodarki Światowej i Integracji Europejskiej
\end{tabular}

MONIKA WOJTAS

mwojtas@hektor.umcs.lublin.pl

\title{
Wzrost znaczenia barier pozataryfowych w polityce handlowej
}

Growing role of non-tariff barriers in trade policy

Slowa kluczowe: polityka handlowa, bariery pozataryfowe, protekcjonizm

Keywords: trade policy, non-tariff barriers (NTB), protectionism

Wstęp

W związku z postępującą od zakończenia drugiej wojny światowej liberalizacją handlu międzynarodowego znaczenie taryf celnych stopniowo spadało. Wraz $\mathrm{z}$ pojawieniem się recesji $\mathrm{w}$ gospodarce podejmowane były jednak próby powrotu do polityki protekcjonistycznej. W związku z tym rosło znaczenie innych niż cła instrumentów, które wywoływały podobny skutek. W przypadku tzw. środków pozataryfowych (non-tariff barriers) często trudniej jest stwierdzić dyskryminacyjny charakter, a zasady ich stosowania wynikają z wewnętrznych przepisów poszczególnych krajów. W związku z tym ustalenie zmierzenia ich zakresu i skutków oraz sformułowanie na forum Światowej Organizacji Handlu wiążących multilateralnych zasad w tym zakresie jest o wiele trudniejsze niż w przypadku ceł.

Celem pracy jest określenie przyczyn stosowania barier pozataryfowych, wskazanie najczęściej wykorzystywanych instrumentów i ocena, jak zmienił się zakres ich wykorzystania, zwłaszcza w ostatnich latach w związku ze światową recesją 2008-2009. 


\section{Pojęcie i przyczyny stosowania instrumentów pozataryfowych}

Instrumenty pozataryfowe definiowane są najczęściej jako inne niż cło instrumenty ograniczające handel. Istnieje bardzo wiele środków, które mogą mieć tego typu charakter. Można je przyporządkować do jednej z następujących grup:

a) środki wpływające na import,

b) środki wpływające na eksport,

c) przepisy wewnętrzne stosowane na terenie danego kraju.

Pierwsze dwie kategorie dotyczą zobowiązań nakładanych na granicy, związanych z przekraczaniem przez towar granicy celnej kraju. Trzecia grupa to tzw. wewnętrzne bariery regulacyjne, nakładane na wszystkie towary będące przedmiotem obrotu w danym kraju (behind-the-border measures). Do tej grupy należą: podatki i inne opłaty, subsydia krajowe oraz wymogi techniczne, dotyczące ochrony zdrowia, ochrony środowiska standardów pracy czy jakości produktów [Staiger, 2012, s. 2].

Obecnie stosowane instrumenty pozataryfowe mogą mieć zarówno charakter tradycyjnych środków polityki handlowej, np. kontyngenty czy subsydia, ale coraz częściej wynikają z innych polityk niż handlowa. Są podyktowane ważnymi celami społecznymi, takimi jak bezpieczeństwo czy ochrona środowiska, jednak ich zastosowanie może powodować niekorzystne skutki dla wymiany międzynarodowej. W takiej sytuacji konieczna jest ocena, czy dotyczą one w takim samym stopniu produktów krajowych, jak i zagranicznych. Często wskazanie środków stosowanych świadomie w sposób dyskryminacyjny jest niemożliwe.

Tabela 1. Klasyfikacja instrumentów pozataryfowych według UNCTAD

\begin{tabular}{|c|c|c|}
\hline \multirow{15}{*}{$\begin{array}{l}\text { Instrumenty } \\
\text { wpływające na } \\
\text { import }\end{array}$} & \multirow{3}{*}{$\begin{array}{l}\text { Instrumenty } \\
\text { o charakterze } \\
\text { technicznym }\end{array}$} & A. Środki sanitarne i fitosanitarne (SPS) \\
\hline & & B. Bariery techniczne w handlu (TBT) \\
\hline & & C. Inspekcja przedwysyłkowa (PSI) i inne wymogi formalne \\
\hline & \multirow{12}{*}{$\begin{array}{c}\text { Instrumenty } \\
\text { o charakterze } \\
\text { nietechnicznym }\end{array}$} & $\begin{array}{l}\text { D. Środki warunkowe: antydumping, cła wyrównawcze i inne środki } \\
\text { ochronne }\end{array}$ \\
\hline & & E. Licencje i kontyngenty ilościowe \\
\hline & & F. Środki wpływające na cenę - podatki i dodatkowe opłaty \\
\hline & & G. Instrumenty finansowe \\
\hline & & H. Środki zakłócające konkurencję \\
\hline & & I. Środki polityki inwestycyjnej, które mogą zakłócać handel \\
\hline & & J. Ograniczenie w zakresie dystrybucji \\
\hline & & K. Ograniczenie dotyczące obsługi posprzedażowej \\
\hline & & L. Subsydia (oprócz subsydiów eksportowych) \\
\hline & & M. Ograniczenia dotyczące zamówień publicznych \\
\hline & & N. Własność intelektualna \\
\hline & & O. Reguły pochodzenia \\
\hline $\begin{array}{l}\text { Instrumenty } \\
\text { wpływające na } \\
\text { eksport }\end{array}$ & & P. Środki wpływające na eksport \\
\hline
\end{tabular}


Konferencja Narodów Zjednoczonych ds. Handlu i Rozwoju (UNCTAD) w 1994 r. rozpoczęła prace nad sformułowaniem definicji i stworzeniem katalogu środków pozataryfowych. Według UNCTAD środki pozataryfowe to wszystkie instrumenty polityki inne niż taryfy celne, które mogą mieć potencjalny, ekonomiczny wpływ na handel międzynarodowy poprzez zmianę ilości wymienianych dóbr lub zmianę ich cen [UNCTAD, 2010, s. xvi]. Klasyfikacja opracowana przez UNCTAD obejmuje instrumenty wpływające na eksport i import. Wśród tych ostatnich wyróżniono bariery o charakterze technicznym i nietechnicznym. Znalazły się tu także wewnętrzne bariery regulacyjne, które najczęściej wpływają na towary importowane. Szczegółowa klasyfikacja została zamieszczona w tabeli 1 . Każdy z 16 rozdziałów (A-P) został podzielony na precyzyjnie zdefiniowane kategorie, a niekiedy podkategorie. Ma to służyć lepszemu gromadzeniu danych, porównywalnych w skali międzynarodowej. Jednocześnie klasyfikacja ta nie ma charakteru historycznego i uwzględnia poprzedzone wieloletnimi badaniami empirycznymi obecnie stosowane instrumenty pozataryfowe.

Podstawowym celem, któremu ma służyć zastosowanie środków pozataryfowych, jest przeciwdziałanie tzw. zakłóceniom rynkowym. Mogą one wynikać między innymi ze zbyt małej ilości rynków, naruszania zasad doskonałej konkurencji przez podmioty rynkowe, efektów zewnętrznych produkcji lub konsumpcji jakiegoś dobra (gdy istnieje różnica pomiędzy społeczną a prywatną, rynkową wyceną kosztów produkcji czy konsumpcji tzw. externalities), [Kjeldsen-Kragh, 2001, s. 97-108]. Konsekwencją niedoskonałości rynków jest obniżenie realnego dochodu społecznego poniżej poziomu optymalnego. W takiej sytuacji obowiązkiem państwa jest usuwanie źródeł zakłóceń, a jeśli jest to niemożliwe neutralizowanie ich skutków. W szczególny sposób dotyczy to zdrowia i bezpieczeństwa konsumentów oraz zapewnienia im prawa świadomego wyboru. Niedoskonałością rynku jest w tym przypadku asymetria informacji między konsumentem a sprzedawcą, która może spowodować zakup produktów np. szkodliwych dla zdrowia lub niebezpiecznych. Celem zastosowanych środków np. w postaci standardów jakości czy wymogów dotyczących oznakowania produktu nie jest ograniczenie handlu, lecz ochrona konsumentów. W podobny sposób można uzasadnić środki, których celem jest zapewnienie ochrony środowiska naturalnego. Jednak instrumenty pozataryfowe mogą być także stosowane w innych celach, takich jak: osiągnięcie większych zysków kosztem partnerów handlowych, pozyskanie kapitału politycznego czy też pod pozorem osiągania celów społecznych stanowić formę ukrytego protekcjonizmu [WTO, 2012, s. 53-57].

\section{Zmiany w stosowaniu instrumentów pozataryfowych w handlu międzynarodowym czlonków GATT/WTO}

Podpisany 30 października 1947 r. układ ogólny w sprawie taryf celnych i handlu (GATT) z założenia dotyczył liberalizacji stawek celnych. Celem twórców GATT było ograniczenie barier w handlu do ceł, jako jedynego w pełni dozwo- 
lonego instrumentu polityki handlowej. Miało to zapewnić większą przejrzystość i przewidywalność w handlu oraz przyczynić się do jego stopniowej liberalizacji [Santana, Jackson, 2012, s. 462]. W układzie zapisany został zakaz stosowania nowych ograniczeń ilościowych oraz nakaz wygaszania istniejących. Klauzula narodowa, która przewidywała obowiązek traktowania produktów importowanych na równi z krajowymi, zakazywała stosowania dodatkowych podatków i opłat. W artykule XX dopuszczano możliwość stosowania instrumentów, których celem miała być ochrona zdrowia i życia ludzi, zwierząt i roślin. Były także ogólne zapisy dotyczące innych środków pozataryfowych (antydumping, określanie wartości celnej itp.). Jednak negocjacje pierwszych rund GATT dotyczyły wyłącznie liberalizacji stawek celnych. Pierwsze próby włączenia instrumentów pozataryfowych miały miejsce w czasie rozpoczętej w 1964 r. rundy Kennedy'ego - efektem było wynegocjowanie tzw. kodeksu antydumpingowego [WTO, 2012, s. 40-41]. Wzrost zaangażowania sygnatariuszy GATT w negocjacje dotyczące barier pozataryfowych nastąpił w czasie Rundy Tokijskiej (1974-1979) [Mucha-Leszko, 2006, s. 20-23] i był wynikiem wzrostu aktywności krajów w zakresie stosowania tego typu instrumentów. Uważa się, że pod koniec lat siedemdziesiątych podlegało im około $20 \%$ produkcji przemysłowej w krajach OECD, a zakres stosowania zwiększył się czterokrotnie [Ostry, 1997, s. 76]. Powrót do protekcjonizmu po latach stopniowej liberalizacji handlu był spowodowany recesją gospodarczą, spadkiem popytu i produkcji oraz wzrostem bezrobocia i deficytu w bilansach płatniczych [Mucha-Leszko, 2005, s. 57]. Wyniki negocjacji Rundy Tokijskiej nie przyczyniły się jednak do znaczącego ograniczenia stosowania instrumentów pozataryfowych. Przełom w tej dziedzinie przyniosła dopiero kolejna runda negocjacji, rozpoczęta w Urugwaju w roku 1986, a zakończona w Marakeszu w 1994 r. W efekcie Rundy Urugwajskiej zakazano stosowania wielu instrumentów pozataryfowych, wynegocjowano wiążące porozumienia dotyczące antydumpingu, subsydiów czy określania wartości celnej towarów, a także środków sanitarnych i fitosanitarnych oraz barier technicznych [Daly, Kuwahara, 1998, s. 207-208].

Skutkiem wynegocjowania nowych reguł dotyczących barier pozataryfowych były zmiany w ich wykorzystaniu przez kraje członkowskie nowo utworzonej Światowej Organizacji Handlu. W tabeli 2 przedstawione zostały główne kategorie notyfikowanych przez członków GATT/WTO barier pozataryfowych. Z danych wynika, że od lat sześćdziesiątych (kiedy rozpoczęto analizę tego typu środków) zdecydowanie spadło znaczenie instrumentów tradycyjnej polityki handlowej, takich jak: ograniczenia ilościowe, licencje czy handel państwowy, a także opłat nakładanych na import. W zamian nastąpił wzrost roli instrumentów nowego typu, mających charakter wewnętrznych regulacji, w szczególności różnego rodzaju barier technicznych. Nastąpił także wzrost znaczenia procedur i formalności celnych związanych $\mathrm{z}$ wprowadzeniem produktu na rynek. 
Pobrane z czasopisma Annales H - Oeconomia http://oeconomia.annales.umcs.pl Data: 26/04/2023 14:14:58

WZROST ZNACZENIA BARIER POZATARYFOWYCH W POLITYCE HANDLOWEJ

Tabela 2. Udział poszczególnych grup instrumentów pozataryfowych w handlu produktami nierolnymi krajów członkowskich GATT/WTO w latach 1968, 1973, 1989, 2003, 2005 (jako \% wszystkich notyfikowanych środków)

\begin{tabular}{|c|c|c|c|c|c|}
\hline Kategoria & 1968 & 1973 & 1989 & 2003 & 2005 \\
\hline $\begin{array}{l}\text { Uczestnictwo rządu w handlu oraz praktyki } \\
\text { restrykcyjne tolerowane przez rządy }\end{array}$ & 11,9 & 15,3 & 20,9 & 7,1 & 7,0 \\
\hline $\begin{array}{l}\text { Procedury celne i administracyjne przy } \\
\text { wprowadzaniu towaru na rynek }\end{array}$ & 14,8 & 14,6 & 11,9 & 23,5 & 26,2 \\
\hline W tym reguły pochodzenia & 1,3 & 0,0 & 0,4 & 7,4 & 2,6 \\
\hline W tym formalności celne & 0,2 & 0,8 & 1,1 & 9,1 & 9,6 \\
\hline Techniczne bariery w handlu & 6,1 & 9,2 & 8,2 & 29,9 & 37,1 \\
\hline Szczególne ograniczenia & 36,7 & 31,5 & 31,7 & 34,9 & 26,8 \\
\hline W tym ograniczenia ilościowe i licencje importowe & 20,7 & 15,6 & 13,9 & 12,8 & 7,0 \\
\hline W tym wymogi dotyczące oznakowania i opakowania & 1,6 & 1,6 & 2,1 & 7,2 & 6,3 \\
\hline Opłaty nakładane na import & 29,2 & 29,4 & 27,3 & 4,4 & 1,1 \\
\hline
\end{tabular}

Źródło: Santana, Jackson, 2012, s. 469.

\section{Stosowanie instrumentów pozataryfowych na początku XXI wieku}

Ocena znaczenia i zakresu stosowania instrumentów pozataryfowych jest trudna ze względu na ich różnorodność oraz brak porównywalnych danych statystycznych. Lukę w dostępności statystyk próbuje zapełnić UNCTAD. Opracowaną metodologię wykorzystano do analizy instrumentów stosowanych przez 30 krajów rozwijających się oraz przez Unię Europejską i Japonię. Obliczone zostały 2 indeksy:

1) indeks częstotliwości (Frequency Index), który odzwierciedla odsetek pozycji taryfowych, w przypadku których są stosowane instrumenty pozataryfowe;

2) indeks pokrycia (Coverage Ratio), który oznacza udział importu objętego środkami pozataryfowymi w całkowitym imporcie kraju.

Na rysunku 1 pokazane zostały wyniki badań w latach 1996-2008. Wynika z nich zdecydowany wzrost obu wskaźników w latach 2001-2004 w porównaniu do lat 1996-2000. W kolejnym badanym okresie zmiany nie były szczególnie wyraźne. Ponadto ponad połowa importu badanych krajów podlegała ograniczeniom pozataryfowym.

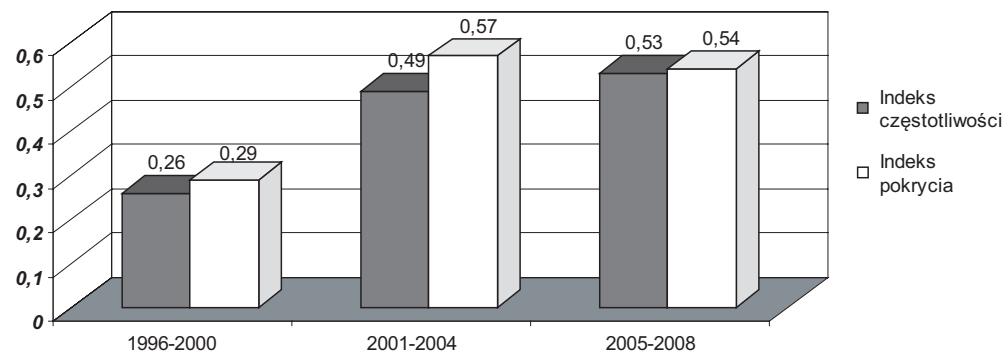

Rysunek 1. Indeks częstotliwości pokrycia w handlu objętym barierami pozataryfowymi w latach 1996-2008

Źródło: WTO, 2012, s. 105. 
264 MONIKA WOJTAS

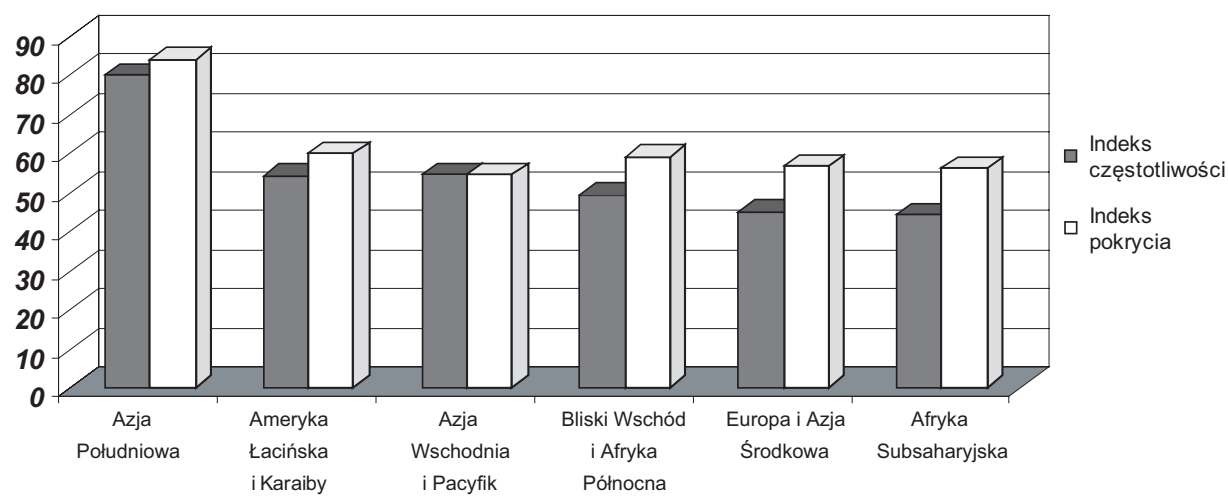

Rysunek 2. Indeksy częstotliwości i pokrycia dla najważniejszych kategorii barier pozataryfowych

Źródło: Cadot, Malouche, Saez, 2012, s. 13.

Znaczenie najważniejszych kategorii barier pozataryfowych zostało pokazane na rysunku 2. Najczęściej stosowane były bariery o charakterze technicznym (TBT), blisko $1 / 3$ pozycji taryfowych i $1 / 3$ całkowitego importu. Kolejną grupą barier w analizowanych krajach były ograniczenia ilościowe, trzecią pozycję zajmowały środki sanitarne i fitosanitarne (SPS). Niewielkie znaczenie miały instrumenty wpływające na poziom ceny. Na rysunku 3 zamieszczono wartość wskaźników częstotliwości i pokrycia dla poszczególnych regionów świata. Największy zakres wykorzystania instrumentów pozataryfowych wystąpił w Azji Południowej - zastosowano je w 80\% pozycji taryfowych i dotyczyły $84 \%$ wartości importu. Najmniejsze znaczenie te bariery miały dla krajów Afryki Subsaharyjskiej - odpowiednio 44,2 oraz 54,6\%.

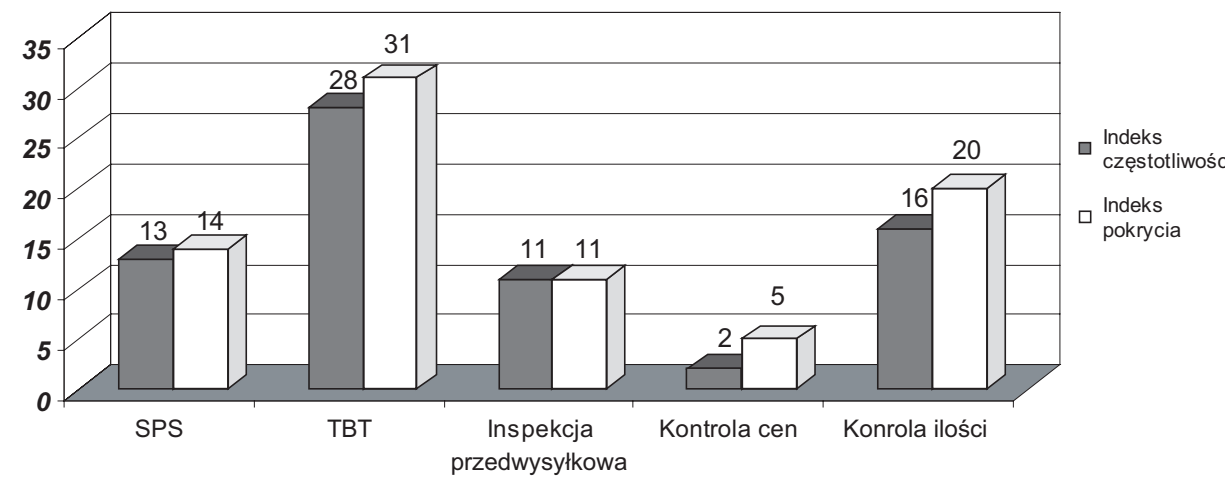

Rysunek 3. Indeksy częstotliwości i pokrycia dla wybranych regionów

Źródło: Malouche, Reyes, Fouad, 2013, s. 4.

W związku z wystąpieniem zjawisk kryzysowych w gospodarce światowej w latach 2008-2009 jako konsekwencji kryzysu finansowego pojawiły się obawy dotyczące możliwości nasilenia się tendencji protekcjonistycznych. Według szacunków WTO 
proces taki nastąpił, ale nie było to zjawisko aż tak znaczące, jak się tego wcześniej spodziewano. Całkowita liczba działań ograniczających handel wzrosła z $53 \mathrm{w}$ roku 2008 do 346 w 2009 r., ale w 2010 r. zaczęła ponownie spadać, a ilość działań protekcjonistycznych była zbliżona do liczby decyzji dotyczących liberalizowania obrotów. Wzrost dotyczył zwłaszcza środków ochronnych, takich jak antydumping czy cła wyrównawcze. Liczba notyfikowanych do WTO interwencji zwiększyła się z 38 w roku 2008 do 196 w roku 2009, ale już w 2010 r. spadła do 104 [WTO, 2012, s. 120].

Podobne dane prezentowane były w przygotowywanych w związku z kryzysem cyklicznych raportach specjalnej grupy roboczej utworzonej przy CEPR. Według danych przedstawionych w tabeli 3 największe znaczenie wśród nowych, zastosowanych w związku z kryzysem instrumentów miała pomoc publiczna $(1 / 4$ wszystkich zastosowanych w latach 2008-2011 środków) oraz środki ochronne (22\%), trzecią pozycję zajęły cła (13\%). Niewielkie znaczenie jako instrumenty ochrony przed kryzysem miały z kolei środki sanitarne i fitosanitarne czy bariery techniczne.

Tabela 3. Udział poszczególnych rodzajów nowych środków ograniczających handel, nałożonych w latach 2008-2011 w całkowitej liczbie zastosowanych instrumentów (w \%)

\begin{tabular}{|l|c|}
\hline Zastosowany instrument & Udział procentowy \\
\hline Pomoc publiczna i bail-out & 25 \\
\hline Środki ochronne (antydumping, cła wyrównawcze i inne) & 22 \\
\hline Cła & 13 \\
\hline Inne bariery pozataryfowe & 7 \\
\hline Podatki i inne ograniczenia eksportowe & 7 \\
\hline Ochrona przed migrantami & 3 \\
\hline Zamówienia publiczne & 2 \\
\hline Środki o charakterze inwestycyjnym & 2 \\
\hline Subsydia eksportowe & 2 \\
\hline Zakazy importu & 2 \\
\hline Finansowanie handlu & 1 \\
\hline Kontyngenty & 1 \\
\hline Środki sanitarne i fitosanitarne & 1 \\
\hline Wymóg składnika krajowego & 1 \\
\hline Subsydiowanie konsumpcji & 1 \\
\hline Bariery techniczne & 8 \\
\hline Pozostałe & 3 \\
\hline
\end{tabular}

Źródło: Evenett, 2012, s. 18.

Pod względem ilości zastosowanych w odpowiedzi na kryzys instrumentów pierwsze miejsce zajęła Unia Europejska, najwięcej pozycji taryfowych dotkniętych ograniczeniami wystąpiło w Wietnamie, najwięcej branż jest w Argentynie, a największą liczbę partnerów, wobec których je zastosowano miały Chiny. Argentyna i Chiny znalazły się na liście top 10 według wszystkich wyróżnionych kryteriów, a Niemcy, Indie i Rosja w 3 z 4 przypadków (por. tab. 4). Należy jednak zaznaczyć, że częstotliwość stosowania środków ograniczających handel nie odzwierciedla precyzyjnie ich restrykcyjności, a liczba pozycji taryfowych lub branż ma charakter formalny. 
Pobrane z czasopisma Annales H - Oeconomia http://oeconomia.annales.umcs.pl

Data: 26/04/2023 14:14:58

MONIKA WOJTAS

Tabela 4. Kraje, które najaktywniej stosowały środki ograniczające handel w latach 2008-2011

\begin{tabular}{|r|l|l|l|l|} 
Lp. & $\begin{array}{c}|c| \\
\text { Według ilości } \\
\text { nałożonych ograniczeń }\end{array}$ & $\begin{array}{c}\text { Według ilości objętych } \\
\text { pozycji taryfowych }\end{array}$ & $\begin{array}{c}\text { Według ilości branż } \\
\text { objętych ograniczeniami }\end{array}$ & $\begin{array}{c}\text { Według ilości partnerów } \\
\text { handlowych dotkniętych } \\
\text { ograniczeniami }\end{array}$ \\
\hline 1 & UE-27 (302) & Wietnam (931) & Argentyna (63) & Chiny (193) \\
\hline 2 & Rosja (169) & Wenezuela (786) & Algieria (62) & UE-27(187) \\
\hline 3 & Argentyna (141) & Kazachstan (732) & UE-27 (57) & Holandia (163) \\
\hline 4 & Indie (74) & Chiny (701) & Chiny (52) & Niemcy (155) \\
\hline 5 & Wielka Brytania (67) & UE 27 (656) & Nigeria (45) & Polska (155) \\
\hline 6 & Niemcy (64) & Nigeria (599) & Rosja (45) & Indie (153) \\
\hline 7 & Francja (61) & Algieria (476) & Niemcy (44) & Indonezja (153) \\
\hline 8 & Chiny (60) & Argentyna (467) & Kazachstan (43) & Belgia (152) \\
\hline 9 & Włochy (56) & Rosja (446) & USA (43) & Finlandia (152) \\
\hline 10 & Brazylia (54) & Indie (401) & Ghana (41) & Argentyna (151) \\
\hline
\end{tabular}

Źródło: Evenett, 2012, s. 38.

\section{Zakończenie}

Wzrost znaczenia barier pozataryfowych można uznać za naturalną konsekwencję liberalizacji w handlu międzynarodowym. Zniesienie najbardziej dotkliwych barier odsłania inne, które do tej pory nie miały tak dużego znaczenia. Ponadto ograniczone zasadami wielostronnego systemu handlu możliwości zastosowania wyższych stawek celnych, kiedy pojawią się ku temu przesłanki (zjawiska kryzysowe w gospodarce), powodują konieczność wykorzystania innych środków. W efekcie powstał szeroki katalog instrumentów, z których korzystają rządy, chcąc ograniczać wymianę międzynarodową. Coraz częściej są to wewnętrzne regulacje państw, a zatem polityka handlowa wykracza poza zakres środków stosowanych przy przekraczaniu przez towar granicy celnej danego kraju. Celem tych instrumentów jest zazwyczaj realizacja ważnego interesu społecznego, np. ochrona zdrowia ludzi czy zapewnienie bezpieczeństwa i jakości produktów dostępnych na rynku. W takiej sytuacji pojawia się problem oceny dyskryminacyjnego charakteru zastosowanego instrumentu. Zdecydowanie trudniejsze jest także mierzenie skutków podjętych działań dla obrotów handlowych. W związku z tym można obserwować zintensyfikowaną aktywność organizacji międzynarodowych zajmujących się handlem i gromadzeniem międzynarodowych statystyk, mającą na celu wypracowanie nowych metod katalogowania i mierzenia efektów barier pozataryfowych. Przedstawione w pracy wyniki tych starań mają wstępny charakter i nie pozwalają na obecnym etapie na precyzyjną ocenę znaczenia barier pozataryfowych w polityce handlowej. Niewątpliwie ich znaczenie rośnie i niezbędne jest wypracowanie nowych międzynarodowych zasad dotyczących ich stosowania. 


\section{Bibliografia}

1. Cadot O., Malouche M., Saez S. (2012), Streamlining non-tariff measures - a toolkit for policymakers, The World Bank, Washington DC.

2. Daly M., Kuwahara H. (1998), The Impact of the Uruguay Round on Tariff and Non-Tariff Barriers to Trade in the "Quad", „The World Economy”, Vol. 21, No. 2.

3. Evenett S.J. (2012), The Landscape of Crisis-Era Protectionism. In Débâcle: The 11th GTA Report on Protectionism (pp. 19-39), London: Centre for Economic Policy Research (CEPR).

4. Kjeldsen-Kragh S. (2001), International Trade Policy, Copenhagen Business School Press.

5. Malouche M., Reyes J.D., Fouad A. (2013), Making trade policy more transparent: a new database of non-tariff measures, „Economic premise”, No. 128, Washington DC, World Bank.

6. Mucha-Leszko B (2006), Problem subsydiów w międzynarodowej polityce handlowej, [w:] B. MuchaLeszko (red.), Systemy wspierania eksportu w Unii Europejskiej a międzynarodowa polityka handlowa, Biuletyn Europejski 2003, Wyd. UMCS, Lublin.

7. Mucha-Leszko B. (2005), Rozwój powiazań w gospodarce światowej-etapy globalizacji i regionalizacja procesów gospodarczych, [w:] B. Mucha-Leszko (red.), Wspótczesna gospodarka światowa - główne centra gospodarcze, Wyd. UMCS, Lublin.

8. Ostry S. (1997), The Post-cold War Trading System: Who's On First?, University of Chicago Press.

9. Santana R., Jackson L.A. (2012), Identifying non-tariff barriers: evolution of multilateral instruments and evidence from the disputes (1948-2011), „World Trade Review”, Vol. 11, No. 3.

10. Staiger R.W. (2012), Non-tariff measures and the WTO, WTO Staff Working Paper ERSD-2012-01.

11. UNCTAD (2013), Classification of Non-Tariff Measures, UNCTAD/DITC/TAB/2012/2, New York and Geneva.

12. UNCTAD (2010), Non-Tariff Measures: Evidence from Selected Developing Countries and Future Research Agenda, UNCTAD/DITC/TAB/2009/3, New York and Geneva.

13. WTO (2012), World Trade Report 2012, Geneva.

\section{Growing role of non-tariff barriers in trade policy}

The goal of the paper is to analyze and explain a growing role of non-tariff barriers (NTB) in trade policy. The author enumerates basic categories of NTB and most important economic reasoning for their implementation as well as presents data on their usage. Basically, NTB spread due to the diminishing role of tariffs. For that reason some of the barriers became more apparent, other starred to be used in place of tariffs. Changing nature of NTB also needs to be pointed out - instead of at-the-border measures, countries use behind-the-border measures meaning internal regulations that are not necessarily aimed at restricting trade, but serve different purposes, such as health or environment protection. It causes new problems stemming from deciding whether a measure is discriminatory as well as makes it harder to negotiate multilateral rules relevant to current trade policy. 